\title{
Ophthalmomyiasis Externa: A Case Report
}

\author{
Eksternal Oftalmomiyazis: Bir Olgu Sunumu
}

\author{
(1) Merve Sena Kundurac1 ${ }^{1}$, (1) Işıl Kutlutürk ${ }^{1}$, (1) Gamze Tanındı Duman ${ }^{1}$, (1) Erdal Polat ${ }^{2}$ \\ ${ }^{1}$ Ümraniye Training and Research Hospital, Clinic of Ophthalmology, İstanbul, Turkey \\ ${ }^{2}$ İstanbul University-Cerrahpaşa, Cerrahpaşa Faculty of Medicine, Department of Medical Microbiology, İstanbul, \\ Turkey
}
Cite this article as: Kunduracı MS, Kutlutürk I, Tanındı Duman G, Polat E. Ophthalmomyiasis Externa: A Case Report. Turkiye Parazitol Derg 2020;44(4):261-3.

\begin{abstract}
Ophthalmomyiasis is the infestation of the eye with fly larvae. Oestrus ovis is one of the most common causes of ophthalmomyiasis worldwide. Herein, we describe a case of external ophthalmomyiasis caused by Oestrus ovis in an 18-year-old female living in the city centre of Istanbul and who had no history of contact with any animal.
\end{abstract}

Keywords: Ophthalmomyiasis, human, Oestrus ovis, Turkey

ÖZ

Oftalmomiyazis gözün sinek larvalarıyla olan enfestasyonudur. Oestrus ovis, Dünya'da oftalmomiyazisin en yaygın nedenlerinden biridir. Burada, İstanbul şehir merkezinde yaşayan ve hayvan temas öyküsü bulunmayan 18 yaşında bir kadın hastada Oestrus ovis'in neden olduğu bir eksternal oftalmomiyazis tanımlanmıştır.

Anahtar Kelimeler: Oftalmomiyazis, insan, Oestrus ovis, Türkiye

\section{INTRODUCTION}

Myiasis is a disease caused by fly larvae of the order Diptera infesting live and dead tissues of humans and vertebrate animals. Infestation of the eye, ear, nose, paranasal sinuses, intestinal and urogenital systems, are seen relatively rarely. Fly species such as Hypoderma, Calliphora, Sarcophaga, Gasterophilus, Cuterebra, Dermatobia are known to cause ophthalmomyiasis $(1,2)$. Oestrus ovis $(O$. ovis) is one of the most common cause of ophthalmomyiasis worldwide. Sheep and goats are the main hosts for this parasite and humans are accidental hosts. These flies are viviparious, i.e., they deposit their first instar larvae directly at the edges of the nostrils of small ruminants like sheep and goats. Thereafter the larvae move into the nasal cavity or sinuses to complete their development. After having left the host animal as third instar larvae they pupate on the soil and become later adult. The infestation of humans usually occurs during close contact with animals such as sheep and goats. It is also possible that the mature fly hits the cornea and causes a direct damage (3).
Based on the site of infestation ophthalmomyiasis is divided into three sub-classes: External, internal and orbital (4). Clinical signs and symptoms also vary depending on the location of infestation. In external ophthalmomyiasis, larvae are observed in the cornea, conjunctiva and eyelid, and cause conjunctivitis-like symptoms such as redness, tearing, edema and foreign body sensation (5). Internal ophthalmomyiasis occurs by invasion of the larvae into the eyeball. It may cause serious complications such as iridocyclitis, vitritis, endophthalmitis and optic atrophy $(6,7)$. Orbital ophthalmomyiasis occurs by larvae penetration into the orbit and affects ocular adnexa and optic nerve (8). We present the case of a 18-year-old female with ophthalmomyiasis due to $O$. ovis larvae. Written informed consent was obtained from the patient.

\section{CASE REPORT}

A 18-year-old female patient presented to our clinic with the complaint of tearing, redness and foreign body sensation in her left eye. In examination, the left eyelid showed mild edema and it was hyperemic,

Received/Geliş Tarihi: 20.11.2019 Accepted/Kabul Tarihi: 02.06.2020

Address for Correspondence/Yazar Adresi: Merve Sena Kunduracı, Ümraniye Training and Research Hospital, Clinic of Ophthalmology, 
visual acuity was 20/20 in both eyes and intraocular pressures were normal. Slit-lamb examination revealed that the right eye was normal; hyperemia and chemosis were detected in the conjunctiva of the left eye and there were many motile larvae on the palpebral and bulbar conjunctiva (Figure 1). Fundus examination was bilateral normal. After anesthetizing the area with $0.5 \%$ Proparakain hydrochloride, the larvae were carefully removed with the help of forceps and sterile cotton swab sticks.

The fornixes were controlled by inverting the eyelids. The eye was washed with saline. The patient was started on topical antibiotic and steroid drops. The patient was called next day for follow-up and no new larva was seen. After 1 week, all symptoms regressed and clinical improvement was achieved.

Larval samples were placed into formaldehyde solution for preservation and sent to the Microbiology Department of Cerrahpaşa Medical Faculty for identification. The larvae were identified as the first instar larva of O. ovis (Figure 2-4).

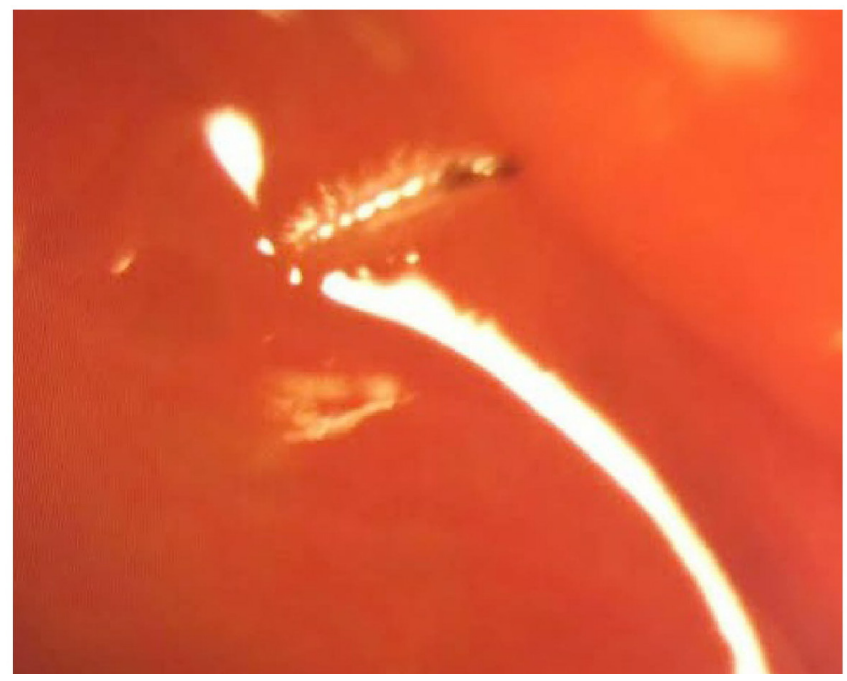

Figure 1. Live larvae located on the conjunctival sac

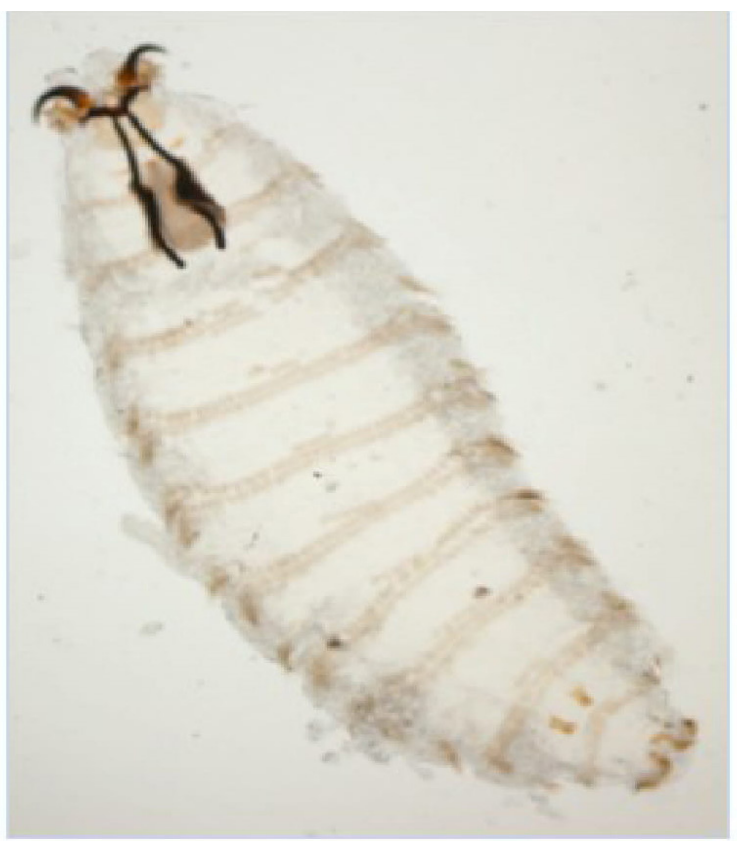

Figure 2. Oestrus ovis first instar larva (10X10)

\section{DISCUSSION}

Ophthalmomyiasis, also known as ocular myiasis, is the infestation of eye or orbital tissues with fly larvae. Since the main hosts of the $O$. ovis are sheep and goats, ophthalmomyiasis is more often reported in people living in rural areas and in veterinarians working in these areas. However, many cases of ophthalmomyiasis from different class of the society have been reported in the literature (9). In line with the literature, our patient was an 18-year-old, living in Istanbul with no animal contact history.

There are reports showing that $O$. ovis larvae can penetrate ocular tissues and cause internal ophthalmomyiasis (10). Most authors believe that the larvae enter the ocular layers of the conjunctival sac by invasion (11). Some authors have claimed $(12,13)$ the possibility of hematogenous entry of the larva and in one reported case the larva entered the eye through the optic nerve head (14). The identification of the isolated larvae is of paramount importance to better understand the damage they are inflicting to the eye. Hypoderma species are often shown as cause of internal ophthalmomyiasis (15).

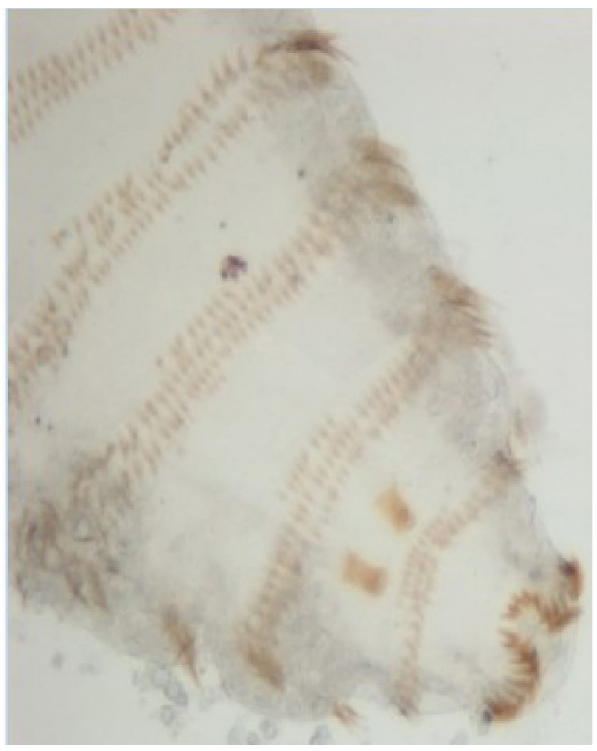

Figure 3. Backward oriented spines arranged in specific order in the larval body segments (10X10)
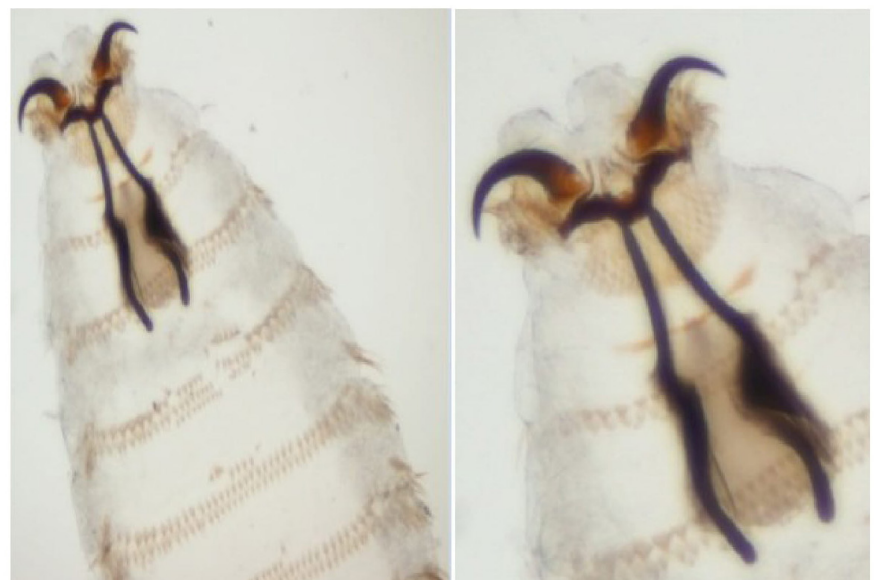

Figure 4. Teeth and pharyngeal scleritis of the larva (10X20) 


\section{CONCLUSION}

External ophthalmomyiasis may also be seen in people living in big cities such as Istanbul. For this reason, external ophthalmomyiasis should be considered when the patients are presented with foreign body sensation and conjunctivitis-like symptoms. Inner eyelid and fornix should be carefully examined. In terms of ocular invasion follow-up, the identification of the larvae is very important. The mechanical cleaning of the larvae is of great importance regardless of the species involved. Patients should be called back for further detection of unrecognized larvae and detailed fundus examinations should be performed for ocular penetration.

\section{* Ethics}

Informed Consent: Written informed consent was obtained from the patient.

Peer-review: Externally and internally peer-reviewed.

\section{* Authorship Contributions}

Surgical and Medical Practices: I.K., G.T.D., E.P., Concept: M.S.K., I.K., Design: M.S.K., Data Collection or Processing: G.T.D., Analysis or Interpretation: I.K., E.P., Literature Search: M.S.K., Writing: M.S.K.

Conflict of Interest: No conflict of interest was declared by the authors.

Financial Disclosure: The authors declared that this study received no financial support.

\section{REFERENCES}

1. Sundu C, Dinç E, Kurtuluş UC, Yıldırım Ö. Ophthalmomyiasis Externa: A Report of Three Cases. Turk J Ophthalmol 2015; 45: 220-2.
2. Köksal M, Altun S, Bayer H. Nadir bir konjonktivit: Eksternal oftalmomiyazis. Turk J Ophthalmol 2014; 44: 316-8.

3. İlhan A, Yolcu Ü, Gündoğan FÇ, Şen A, Akay F. Oftalmomiyazis eksterna: Olgu sunumu. TAF Prev Med Bull 2015; 14: 177-80.

4. Sharma K. Ophthalmomyiasis externa: A case report from Alkharj, Saudi Arabia. Saudi J Ophthalmol 2018; 32: 250-2.

5. Çelik T. Bilateral eksternal oküler enfestasyon ile seyreden bir miyazis olgusu. Turk J Ophthalmol 2014; 44: 256-8.

6. Jakobs EM, Adelberg DA, Lewis JM, Trpis M, Green WR. Ophthalmomyiasis interna posterior. Report of a case with optic atrophy. Retina 1997; 17: 310-4.

7. Gözüm N, Kir N, Ovali T. Internal ophthalmomyiasis presenting as endophthalmitis associated with an intraocular foreign body. Ophthalmic Surg Lasers Imaging 2003; 34: 472-4.

8. Caça I, Unlü K, Cakmak SS, Bilek K, Sakalar YB, Unlü G. Orbital myiasis: case report. Jpn J Ophthalmol 2003; 47: 412-4.

9. Carillo I, Zarratea L, Suarez MJ, Izquierdo C, Garde A, Bengoa A. External ophthalmomyiasis: a case series. Int Ophthalmol 2013; 33: 167-9.

10. Rakusin W. Ocular myiasis interna caused by the sheep nasal bot fly (Oestrus ovis L.) S Afr Med J 1970; 44: 1155-7.

11. Syrdalen P, Nitter T, Mehl R. Ophthalmomyiasis interna posterior: report of case caused by the reindeer warble fly larva and review of previous reported cases. Br J Ophthalmol 1982; 66: 589-93.

12. Mason GI. Bilateral ophthalmomyiasis interna. Am J Ophthalmol 1981; 91: 65-70.

13. Byers B, Kimura SJ. Uveitis after death of a larva in the vitreous cavity. Am J Ophthalmol 1974; 77: 63-6.

14. De Boe MP. Dipterous larva passing from the optic nerve into the vitreous chamber. Arch Ophthalmol 1933; 10: 824-5.

15. Lagace-Wiens PR, Dookeran R, Skinner S, Leicht R, Colwell DD, Galloway TD. Human ophthalmomyiasis interna caused by Hypoderma tarandi, Northern Canada. Emergy Infect Dis 2008; 14: 64-6. 